\title{
The Application of Women Wearing Head Covering and Their Role in Ministry - Based on 1 Corinthians 11:3-6 and 14:34, 35
}

\author{
Milton T. Pardosi ${ }^{1}$ \\ ${ }^{1}$ Faculty of Philosophy, Universitas Advent Indonesia, Indonesia \\ Correspondence: Milton T. Pardosi, Faculty of Philosophy, Universitas Advent Indonesia, Indonesia.
}

Received: November 11, 2017

Accepted: December 25, 2017 Online Published: December 27, 2017

doi:10.20849/ajsss.v2i4.264

URL: https://doi.org/10.20849/ajsss.v2i4.264

\begin{abstract}
1 Corinthians 11:3-6 and 14:34, 35 are two of controversial passages in the New Testament. The present study was done to evaluate some issues. They are: (1) The meaning of "Headship?" (2) The meaning of "head-covering as a mark of subordination?" (3) Women's role in the church or ministry? (4) The last, do women in Moslem countries or in non-Moslem Countries have to wear head coverings after they convert to Christianity? The results are: (1) Headship's concept is the concept of love not oppression as God is head of Christ; Christ is head of man; man is head of woman in love's perspective. The word "head" in "headship" means "source"; (2) Head coverings is a custom for Corinthians' women, and it is a must in honoring their custom and to distinguish themselves from idolatrous women and prostitutes; (3) Women still have their roles in ministry. Women are a part of God's ministry; (4) For Christians today, they may follow their customs as long as the customs are not against the word of God; or, if the custom is identical to a particular religion, then Christian must avoid it for it will cause misunderstanding for other people.
\end{abstract}

Keywords: headship, head covering, role

\section{Statement of the Problems}

There are some issues will be discussed in this writing:

(1) What is the meaning of "Headship" in 1 Corinthians 11:3-6?

(2) What is the meaning of "head-covering as a mark of subordination" in 1 Corinthians 11:3-6?

(3) How is women's role in the church or ministry as the application of 1 Corinthians 14:34, 35?

(4) The last, in the countries where most of the populations are Moslem or Moslem countries using head coverings is a must. The question is what to do if women in these Moslem countries convert to Christianity? Do they have to wear head coverings in the church? How about for women who are not living in Moslem countries? Do women in such countries have to wear veil (head coverings) when they come and participate in church service?

\section{Purposes of Study}

Through this paper, readers may have right perceptions in what Paul was saying according to the context of 1 Corinthians. They are:

1. Readers may understand the meaning of "Headship" based on 1 Corinthians 11:3-6.

2. Readers may understand the meaning of "head-covering as a mark of subordination" based on 1 Corinthians 11:3-6.

3. Readers may know the women's role in the church or ministry as the application of 1 Corinthians 14:34, 35 .

4. For those who live in Moslem countries or those who convert to Christianity from Moslem background, the issue of wearing head coverings or not will not be an issue anymore in the church.

\section{Limitations}

The limitation of this paper is in the context of 1 Corinthians only. The writer tried to find out the background of these two passages and the condition of the church of Corinth and its culture at the time of apostle Paul. 


\section{Methodology}

The writer applied the grammatical-biblical method of exegesis to solve problems being undertaken in this study. Some sources were used such as: The Bible as the primary source; others are theological dictionaries, concordances, lexicons, commentaries, etc. as secondary sources.

\section{Analysis}

In this discussion, the writer divided the study into three parts: first, Paul's concept in "Headship;" second, the context of "head-covering as a mark of subordination;" and third, women's role in ministry.

\subsection{Paul's Concept in "Headship"}

In 1 Corinthians 11:3, Paul wrote: "But I would have you know, that the head of every man is Christ; and the head of the woman is the man; and the head of Christ is God" (King James Version). The ranks and relations of Christian fellowship, as organized on the basis of redemption, are here brought forward (see Eph. 5:21). Paul mentions four individuals or groups among whom God has an order of headship. The order is God, Christ, man, woman. As we know, Christ is equal to the Father in nature, but His role, while was living in this world as a man, was subject to the Father. Jesus said: "I seek not mine own will, but the will of the Fathers which hath sent me" (John 5:30, KJV). Similarly, men and women are equal in many things as Paul said: There is "neither male nor female" in our standing in Jesus Christ (Galatians 3:28).

Now, what is the meaning of "head" in 1 Corinthians 11:3? There are three suggestions about it. First, the Greek term kephale, besides its natural significance, is used: (a) figuratively as in Romans 12:20; (b) metaphorically, of the authority or direction of God in relation to Christ, of Christ in relation to believing men, of the husband in relation to the wife (W.E. Vine, 1961, p. 202). In 1 Corinthians 11:3, the word "head" is used as a metaphorically. "Head" in metaphorical sense means as in the body, the members of the body are subject to the head; the family is subject to the husband; the state is subject to the king; the church is subject to Christ; and Christ Himself is subordinate to the Father (F.C. Cook, 1981, p. 318).

Second, "The Greek term kephale (in Hebrew: rosh) can mean chief or person in charge. The word Kephale appears 281 times in the LXX as the translation of Hebrew word rosh. This Hebrew word occurs twenty five times in Exodus, and the LXX renders it regularly by kephale when used in literal sense, but not in the texts where rosh means "ruler" (Joseph A. Fitzmyer, S.J. 1993, p. 82). The Hebrew word for head, rosh, when it refers to a leader, is usually translated in the Septuagint by the Greek word arche, meaning ruler (Fitzmyer, p. 82). At the same time it can also mean source, such as head of a river. The translation 'source' seems best for a passage like 1 Corinthians 11:3 that reflect so much on the origin of man and woman in the Genesis creation story" (Graydon F. Snyder, 1992, 149).

If we study Greek Grammar, it has two prepositions ( $e k$ and $d i a$ ) to explain two different things. The prepositions make it clear that Paul is thinking of head as source in 1 Corinthians 11:3. If we noticed, Paul used "ek" (from) as source, and "dia' (through or by) as agent in 1 Corinthians 11:8, 12. These two verses are the best examples for these two prepositions. In these passages, Paul makes it clear that woman is $e k$ (from) man not vice versa (bone $e k$ [from] my bone, and flesh $e k$ [from] my flesh, Gen. 2:23), but woman is the agent through (dia, v. 12b) whom man is born (Snyder, p. 150). It means, God as the source of Christ, Christ as the source of man, and man as the source of woman. So the translation as quoted by Joseph Fitzmyer is: "I want you to know that every man's source is Christ; the source of woman is man, and the source of Christ is God" (Fitzmyer, 1939, p. 82).

Third, "there is a difference between the headship of God and the headship of Christ and between the headship of Christ and of the man, still a common element is discernible in the three, and that authority is springing from union. The man is head of woman in virtue of the marriage union; Christ is head of man in virtue of union through faith; God is head of Christ in consequence of Fatherhood and Sonship" (Thomas Charles Edwards, 1979, p. 271).

By these three definitions, I considered to translate (The source of man's (or husband) authority on woman (or wife) is Christ, the source of Christ's authority on man is God, and the source of woman's authority on her head is man). It is supported by Ivan T. Blazen. He mentioned that "head" is used to indicate the source through which authority is derived. The authority is actual but connected with another. If one's authority is derived, that person should not act in independence but in concert (Ivan T. Blazen, 1977, 83-84).

But the other question, however, is what sense should be attributed to the term in 1 Corinthians 11:3? "Paul speaks of the man (Adam) as his wife's 'source' just as Christ has created Adam and later proceeded from the Father in His incarnation (in which 1 Cor. 11:3 is in Chronological sequence) (Gerald F. Hawthorne, 1993, p. 586). On the other hand, the word "head" in this passage is a clarification of human being's source (Lawrence O. Richards, 1985, p. 328). This defines the flow of the creation order: Christ flowed from God; man came into being by Christ's 
activity as Creator; and woman was taken from the side of man. There is no suggestion here inferiority, for Jesus is and always was the complete equal of the Father (Richards, p. 328).

Man and woman were created by God, woman's source (head) is man, and man's source (head) is Christ, and Christ's source (in His incarnation but not in His natural as God) is Father. Christ is not lower or higher than God, because They are one and equal (John 1:1-3; 10:30). In this passage, Christ in His nature is not subordinate to Father but when He was as a man (in His incarnation), Christ was subject to the Father, since God did not create Jesus in heaven, and both of Them have no beginning.

In 1 Corinthians 11:3, Paul wanted to say that in public worship women should treat man as the "head." Paul meant that man is head of woman. Here, "The woman while recognizing the supremacy of Christ as Lord over all is required to acknowledge that in domestic life, she is placed under the guidance and protection of man. The power and dignity of the husband depends on the position toward Christ, his head, therefore the dependence of the wife on her husband is in the true sense dependence on Christ through the husband. The dependence of the wife on her husband was a divinely appointed plan for the good of both spouses" (Francis D. Nichol, Vol. 6, p. 754). In the same way as Christ is the head of man; women are not inferior to men; and also woman should be partners with men, both in marriage and in the church congregation; should be the partners rather than the servants of men (John Hargreaves, 1978, p. 144). We have to understand the concept of Paul according to Ephesians 5:22-26 and Colossians 3:18 since without these passages, Bible readers will have wrong concept about "head" between man and woman in the Bible. Therefore, the notions included in term "head" the headship of which the apostle speaks means authority having union for its ground and redemption for its subject (Edwards, pp. 271-272). "For instance, the authority of the man over the woman is here based on the Christian idea of marriage as the marriage-union borrows new characteristics from the union between Christ and the church. Again, the authority of Christ over the man is based on Christ's redemptive work and has for its aim the advancement of Christ's kingdom. Once more, the authority of God over Christ, though ultimately derived from God's fatherhood, actually regards Christ, not only as Son, but as God-Man and mediator" (Edwards, 271-272).

\subsection{Head-Covering as a Mark of Subordination}

Paul wrote in 1 Corinthians 11:4, 5 "Every man praying or prophesying, having his head covered, dishonors his head. But every woman who prays or prophesies with her head uncovered dishonors her head; for that is one and the same as if her head were shaved" (NKJV). Christians have to recognize in what situation Paul said this passage. First, Bible readers have to know in where Paul prohibited woman to pray and prophecy without head covering. In this passage, we have seen that Paul wanted women to veil themselves when they speak in the congregation for that would be suit to the customs of Corinth. But in vv.3-9 Paul wanted to maintain the sexual differentiation God had created, not the sexual identification (Blazen, p. 83). Here, Paul gave another reason why women should wear veils: 'because God created man to be head of a woman.' When a woman wore a veil it was a sign that she accepted a man as head (Hargreaves, p. 144).

Second, what was the culture in Corinth at Paul's time?

At that time "Roman women (like Roman men) covered their heads in worship, in contrast to Greek women and men. The Corinthian church, located near a major port and born in a synagogue (Acts 18:4, 7-8), probably included a number of Eastern immigrants for whom the covering was an important practice" (Hawthrone, p. 585). In other words, "women were not highly prized in either Hebrew or Graeco-Roman culture. A woman was under the authority of either her father or her husband; she could not testify in a court law; she could not inherit property; she could not claim the right education. In Hebrew world it was not much different. Women had no rights, no education. They sat in a gallery in the synagogue. They could not share on its leadership as leaders. By the time of Jesus, women took no part in public life, were so heavily veiled that a man could not recognize his own mother, and were thoroughly downtrodden. 'It is better to burn Torah than to teach it to women,' said the rabbis, and many Jewish men gave thanks to God daily, 'Blessed be God who has not made me a heathen, a slave or a woman." (Michael Green, 1982, p. 152-153).

How about in the Corinth society?

In Corinth itself there was a great temple to Aphrodite the prostitute on the Acrocorinth, and thousand prostitutes operated there in service of the goddess of love. Their faces were heavily made up, and they wore no bands in their hair, no veils, and a short, brightly colored tunic instead of the normal long garment of the Roman matron (Green, pp. 153-4). The old religion of Rome was in decay, and by the first century was being replaced by many cults from the East, most of which gave a prominent and unhealthy position to women. Women took leading parts in the mystery religions (Green, 152-153). 
How about women in the Corinth church? What was going on there, so this became an issue? Women in Corinth had wrong interpretation about their freedom in Christ. They believed that uncovering head as a symbol of freedom in Jesus Christ, because man and woman are equal in Jesus (Blazen, p. 83). It was a kind of liberation movement, as a mark of spiritual endowment, freedom and identification with men (Blazen, 83).

A woman praying and prophesying without a head covering in the ethically and socially diverse Church of Corinth might have been a source of offense to some, and a disturbing attraction to others. In that situation, nothing detracts from God's glory, women's head needed to be covered. Uncovered women in worship might be associated with women with long, uncovered hair who worshipped in some of the pagan mystery religions (Blazen, pp. 82-3).

Why did Paul compare women without head covering with women were shaved?

The probability then would be that the Christian woman with unduly short hair is being likened either to a Corinthian prostitute or even to an adulteress. Paul's point, which is incontestable, is meant that she is unfitted to approach the God who gave her long hair; when praying and prophesying she would expose herself indecently before Majesty. His sole implication is that the woman who shortens her hair makes herself out to be a man, willful act of self-exposure that cannot be right (Peter Naylor, 1996, p. 206).

Anyway, wearing a head covering for women at Paul's time (at Corinth) was required when they were praying or prophesying in the Church or congregation since head covering was a custom for women in Corinth (Richards, $p$. 328). Thus, Paul's appeal is not women take a subordinate place in the church. His appeal is that they recognize the fact an order in creation that is unchanged by the wonderful message that in Christ are equal (Gal. 3:26-28) (Richards, p. 328). For a woman with head uncovered would give the impression that she acted shamelessly and immodestly, without the adorning of shame-facedness and sobriety. It was also a symbol or an evidence that she already married, and as a matter of modesty (Nichol, Vol. 6, p. 756). In the Corinthians' society, head covering (Nichol, Vol. 6, p. 756) was a sign of the distinction between women and men, between good women and not. At the same time, veil is a sign that she admitted that man or her husband as her "head" (source).

In any case, women are to continue in leadership roles, with their power, their authority, on their head. In the eyes of society they will disgraced themselves if they take off their identifying mark as a woman and a wife. Presumably such a change in dress would identify them in temple prostitution or other seductive groups in the social life of Corinth. Even women of the new age would be conscious of that kind of social statement (Snyder, p. 154).

There is no evidence that the Corinthian women had already begun a practice contrary to what Paul was teaching.

But some women in Corinth tried "with a strong conscience thought their leadership role and their freedom in Christ released them, at least temporarily, from symbolic attachment to their husband and their family. They could dress as they wished, even like prostitutes or like men (Shaved)" (Snyder, p. 151).

For women (Richards, p. 328) who had been favored with spiritual gifts, they were not released from their subordinate role and also from the customary society marks of that subjection (Richards, 328). What is woman going to do? Richards suggests simply this: she must live within the culture as a woman rather than deny her womanhood by dressing as would a man. A woman in the Corinthian church was to pray and prophesy with head veiled, and a man in Corinth church was to function with head unveiled. A man can be proud of his place as a man. And a woman can be equally proud of her place as a woman (Richards, p. 328). Paul was not dictating social custom. He did base a portion of his argument to the Corinthians on their local customs. If it is so, what women should do with this passage? Blazen gives some suggestion (Blazen, p. 86):

1. It is important to be modest in dress worship.

2. If the way we dress is discomforting to other worshipers, we should avoid it, for we are on body in Christ.

3. If our disregard of cultural conventions offends non-members and makes it difficult for them to come to Christ, we should think not merely of our own freedom but of their salvation.

4. In harmony with God's intention in creation, while working for unity, we must still preserve the differences between the sexes, and not do away with symbolic gender distinctions.

5. When culture conflicts with Christ, we must reject it, but when it may be used for Christ, we should respect it.

\subsection{Women's Role in Ministry}

In 1 Corinthians 14:34, 35 "women should remain silent in the churches. They are not allowed to speak ...; for it is disgraceful for a woman to speak in the church." If we compare to 1 Corinthians 11:4-6, it seems both are contradicted to each other, since Paul allowed woman to pray and prophesy with veil in the church. "Many scholars say that this passage has been added to 1 Corinthians 14 , since v. 37 really ought to follow v. $33 \mathrm{~b}$, but 
other copyists, knowing there was nothing about women keeping silent in other manuscripts, placed the verses at the end of the chapter. So there is fairly strong agreement about vv. 34-35. They must not have been a part of the original text" (Snyder, p. 185).

Whether it is true or not, let us look back to the background of this passage? First, Paul considered that woman should remain silent only in the church not in other place, since Paul did not mention about other place in his message. Second, why did Paul consider it just for women not to every one? As the writer mentioned above, at that time, women, "perhaps because among non-Christian at that time women were were not educated and not accustomed to speaking in public. When they became Christian they were tempted to talk too much because it was something they had never done before" (Hargreaves, p. 183). They did not have right as men (Hargreaves, p. 183). They could not sit with men in the church; they will sit in the backside of the church, and were uneducated. So they could not hear clearly what a preacher was saying, and they would ask many questions because they did not understand the message. This situation will disturb the worship. "Such a procedure would prevent unseemly interruptions in the service of worship and avoid the confusion attendant on such interruptions" (Nichol, Vol. 6, p. 793).

What is the meaning of "speak" in v. 34? If we look carefully Paul used "lalein" for "speak." This word has been employed a good deal in this chapter for "speak in tongues." It may be that he is here discouraging women from undisciplined and indiscriminate speaking in tongues during the service and so causing disorder. In other way, this word also is often used for informal chattering (Green, p. 158). I have two suggestions about this verse: first, I considered Paul prohibited women chattering in the church by asking her husband not in praying and prophesying as mentioned in 1 Corinthians 11:3-6 and let women ask their husband at home about the sermon. Second, Paul prohibited women to speak in tongues in the church without discipline and orderliness as he mentioned in 1 Corinthians 14:1-25.

In these verses, Paul does not change his mind with his statement in 1 Corinthians 11:3-6 and his approval to encourage women to serve God or does not agree with other texts in the Scripture about women's role in ministry (Romans 16:1-4, 7,12; 1 Corinthians 16:19, 2 Timothy 4:19; Philippians 4:2-3) . In this case, he was trying to encourage women in Corinth Church to exercise their ministers in ways that do not undermine the headship of their husband at least, if not male's headship in general. He also encouraged women to use their spiritual gifts according to God's rule as he mentioned and do not interrupt by asking something in the church because it would disturb the congregation in worshiping God for most of them are uneducated people.

\subsection{Wearing Head Coverings in Modern Times}

In countries where wearing head covering is a must, then, for women who convert to Christianity, it is not prohibited to wear their head coverings in their daily life and when come to the church. Here are the explanations. First, if wearing head covering is just a culture for certain countries, then as good Christians, women, especially, need to follow that culture. Second, if wearing head covering is not identical to a particular religion, then, it is not a mistake to wear head covering. But if it is identical to a particular religion, then, good Christians must remove it.

For women who are living in countries where head coverings is not a must or part of cultures or identical to a particular religion, then Christian women are free to decide whether they are going to wear head covering or not. But, everyone should respect other decision and understanding about it without giving judgment on others decision.

\section{Conclusion}

Here there are four conclusions about problems as mentioned above:

1. Headship's concept is the concept of love not oppression as God is head of Christ; Christ is head of man; man is head of woman in love's perspective not as slave. The word "head" in "headship" should be understood metaphorically. It means source. God is source of Christ (in His incarnation); Christ is source of man; and Man is source of woman.

2. Using veil for women was only for women in Corinth not for every woman all over the world at Paul's time. A veil or head coverings is a custom for Corinthians' women, and they must use it to honor their custom and to distinguish themselves from idolatrous women and prostitutes.

3. All women from Genesis until now still have their roles in ministry (Judges 2:11, 12; 2 Kings 22:14; Luke 2:36, 37; Acts 21:9; Phil. 4:3) and on top of it, in the last days as Joel mentioned in Joel 2:28-29, women (daughters) will prophesy as man (sons). Women are part of God's ministry, men's partner. So, the church should encourage women to be more active in church's ministry. Women have to use their freedom in the plan of salvation. 
4. For Christians today, they may follow their customs as long as they are not against the word of God. But in other way, leave it, if the customs are in contradiction to God's word. Or, if the custom is identical to a particular religion, then Christian must avoid it for it will cause misunderstanding and even becomes stumbling block for other Christians and non-Christians.

\section{References}

Blazen, Ivan T. (1977). The Gospel on the Street. Canada: Pacific Press Publishing Association.

Cook, F.C. (1981). The Bible Commentary. Vol. 9. Grand Rapids: Baker Book House.

Edwards, Thomas Charles. (1979). A Commentary on the First Epistle to the Corinthians. Minneapolis: Klock \& Klock Christian Publishers.

Fitzmyer, Joseph A. (1993). According to Paul. New York: Paulist Press.

Gerald F. Hawthorne. (1993). Dictionary of Paul and His Letter. Leicester: Intervarsity Press.

Graydon F. Snyder. (1992). A Faith Community Commentary. Georgia: Mercer University Press.

Green, Michael. (1982). To Corinth with Love. London: Hodder and Stoughton.

Hargreaves, John. (1978). A Guide to 1 Corinthians. London: SPCK.

Nichol, Francis D. Ed. (1957). Seventh-day Adventist Bible Commentary, Vol. 6. Washington D.C.: Review and Herald Publishing Association.

Peter Naylor. (1996). 1 Corinthians. Great Britain: The Bath Press.

Richards, Lawrence O. (1985). Expository Dictionary of Bible Words. Grand Rapids: Zondervan.

Snyder, Graydon F. (1992). A Faith Community Commentary. Georgia: Mercer University Press.

Thomas Charles Edwards. (1979). A Commentary on the First Epistle to the Corinthians. Minneapolis: Klock \& Klock Christian Publishers.

Vine, W.E. (1961). An Expository Dictionary of New Testament Words. London: Oliphants Ltd.

\section{Copyrights}

Copyright for this article is retained by the author(s), with first publication rights granted to the journal.

This is an open-access article distributed under the terms and conditions of the Creative Commons Attribution license (http://creativecommons.org/licenses/by/4.0/). 